\title{
HUBUNGAN KONSTRUK SERVICESCAPE DAN KEPUASAN \\ KONSUMEN COFFE SHOP DI KOTA JAMBI
}

\author{
Musnaini \\ Management Department of Economic and Business Faculty \\ Universitas Jambi, Jambi, Indonesia
}

\begin{abstract}
ABSTRAK
Tujuan penelitian ini untuk menjelaskan hubungan antara Servicescape yaitu Ambient Condition(X1), Spatial Layout/Function(X2) dan Sign Symbol/Artefac (X3) dan Kepuasan Konsumen Coffee Shop di kota Jambi. Penelitian ini menggunakan pendekatan eksplanasi. Pengumpulan data dengan kuisoner kepada 100 responden secara Judgmental Sampling. Model penelitian diolah menggunaka regresi berganda dengan software IBM SPSS Statisctics 25. Hasil analisa membuktikan bahwa secara simultan terdapat hubungan disignifikan antara dimensi Servicescape terhadap kepuasan konsumen Coffee Shop di kota Jambi. Ternyata secara parsial kepuasan konsumen Coffee Shop di jambi dominan dipengaruhi oleh dimensi Spatial Layout/Function yaitu sebesar 13,54\%.

Kata kunci : Servicescape, Kepuasan Konsumen, Coffee Shop
\end{abstract}

\section{PENDAHULUAN}

Saat ini pertumbuhan bisnis caffeshop sangat cepat dan pesat hampir di seluruh kota di Indonesia, tidak terkecuali di Kota Jambi (Detik, 2019). Setiap orang sudah familiar dengan Coffee Shop sebagai tempat berkumpul atau melakukan kegiatan bisnis maupun untuk kebutuhan aktualisasi diri di lingkungan sosial. Paradigma sosial masyarakat tradisional mengalami perubahan gaya hidup (lifestyle) modern, simple dan trendi akan tercermin dari perilaku mereka memilih tempat untuk berkumpul.

Salah satu manifestasi gaya hidup modern saat ini adalah kebiasaan kelompok masyarakat tertentu untuk hangout di kafe atau Coffee Shop. Bagi marketer Coffee Shop harus menyadari bahwa pola masyarakat terhadap tempat ngopi atau "ngopi bareng" bukan lagi sekedar untuk menghilangkan kantuk, tapi sebagai bagian gaya hidup, dimana Coffee Shop merupakan tempat sangat diminati. Sehingga persaingan Coffee Shop sangat ketat dalam memberikan pelayanan terbaik bagi konsumennya.

Untuk tetap survive dalam bisnis Coffee Shop kuncinya adalah kepuasan 
pelanggan atau konsumen. Dengan memberikan pelayanan dan panyajian produk berkualitas diharapkan mampu mempertahankan konsumen atau menarik konsumen baru. Ferninda, (2013) mengatakan bahwa pelayanan prima dengan memperhatikan aspek lingkungan berupa servicescape mampu mempengaruhi kepuasan pelanggan.

Fenomena tumbuh kembangnya Coffee Shop di kota Jambi mengindikasikan bahwa salah satu tugas berat bagi pemasarnya yaitu menerapkan serviscape yang baik di Kota Jambi. Maka penelitian ini berupaya menelaah hubaungan servicescape berupa Ambient Condition, Spacial Layout/Function dan Sign Symbol/Artefac terhadap kepuasan konsumen Coffee Shop di Jambi.

\section{Perumusan Masalah}

Permasalahan yang diangkat dalam penelitian ini adalah sebagai berikut:

1. Apakah secara parsial servicescape (Ambient Condition, Spacial Layout/Function dan Sign Symbol/Artefac) mempengaruhi kepuasan konsumen Coffee Shop?

2. Apakah secara simultan servicescape (Ambient Condition, Spacial Layout/Function dan Sign Symbol/Artefac) mempengaruhi kepuasan konsumen Coffee Shop?

3. Apakah ada perbedaan yang signifikan antara dimensi Ambient Condition, Spacial Layout/Function dan Sign Symbol/Artefac mempengaruhi kepuasan konsumen Coffee Shop?

\section{Tujuan Penelitian}

Tujuan dari penelitian ini adalah :

1. Untuk menganalisa dan menjelaskan pengaruh parsial servicescape (Ambient Condition, Spacial Layout/Function dan Sign Symbol/Artefac) terhadap kepuasan konsumen Coffee Shop

2. Untuk menganalisa dan menjelaskan pengaruh servicescape (Ambient Condition, Spacial Layout/Function dan Sign Symbol/Artefac) terhadap kepuasan konsumen Coffee Shop secara holistik.

3. Untuk menganalisa dan menjelaskan dominansi dimensi Servicescape (Ambient Condition, Spacial Layout/Function dan Sign Symbol/Artefac) terhadap kepuasam konsumen Coffee Shop. 


\section{TINJAUN PUSTAKA}

\section{Servicescape}

Pengertian "servicescape merupakan kesan-kesan yang diciptakan pada panca indra oleh perancangan lingkungan fisik tempat jasa diserahkan (Lovelock dan Wirtz (2014). Physical evidence atau bukti fisik dari karakteristik jasa merupakan salah satu unsur penting dalam pemasaran jasa.

Defiisi bukti fisik jasa meliputi semua aspek fasilitas fisik organisasi (servicescape) dan juga bentuk komunikasi fisik lainnya (Zeithaml dan Bitner 2006). Model Bitner ini menunjukan bahwa lingkungan jasa yang sama dapat memberikan dampak berbeda terhadap berbagai pelanggan, sesuai dengan pandangan, pengalaman dan mengandung makna subjektifitas.

Dengan kata lain bahwa pemahaman terkait servicescape yaitu subyektifitas pandangan konsumen terhadap lingkungan yang disediakan oleh penyedia jasa untuk berinteraksi dengan konsumen dan didukung oleh fasilitas-fasilitas fisik yang menunjang keberlangsungan proses penyampaian jasa serta dapat menciptakan kesan yang berbeda-beda pada setiap perusahaan penyedia jasa.

\section{Kepuasan Konsumen}

Pengertian kepuasan konsumen menurut Zeithaml dan Bitner (2003) yaitu respon atau tanggapan konsumen mengenai pemenuhan kebutuhan. Kepuasan merupakan penilaian mengenai ciri atau keistimewaan produk atau jasa, atau produk itu sendiri, yang menyediakan tingkat kesenangan konsumen berkaitan dengan pemenuhan kebutuhan konsumsi konsumen. Kepuasan konsumen dapat diciptakan melalui kualitas,pelayanan dan nilai.

Kotler and Keller (2013) menjabarkan kepuasan konsumen sebagai refleksi perasaan senang atau kecewa seseorang yang mucul setelah membandingkan hasil kinerja (hasil) produk yang dipikirkan terhadap kinerja (atau hasil) yang diharapkan. Kepuasan konsumen merupakan faktor awal yang mempengaruhi intensitas konsumen dalam melakukan pembelian berulang menjadi lebih tinggi. Tentu saja setiap perusahaan menginginkan terjadinya pembelian yang berulang dari setiap konsumen yang dimilikinya. 


\section{METODE PENELITIAN}

\section{a. Populasi}

Populasi yang akan diambil pada sampel ini adalah seluruh masyarakat kota Jambi tahun 2018 sebanyak 3.570.272 jiwa (Badan Pusat Statistik Provinsi Jambi, 2019).

\section{b. Sampel}

Teknik pengambilan sampel pada penelitian ini adalah non-probability sampling. Nonprobability sampling adalah teknik pengambilan sampel yang tidak memberi peluang/kesempatan yang sama bagi setiap unsur atau anggota populasi untuk dipilih menjadi sampel. Karakteristik responden yaitu (1) pengunjung Coffee Shop lebih dari 5 kali setiap bulan, (2) mengetahui lebih dari 3 (tiga) coffe shop di kota Jambi. Ukuran sampel yang digunakan dapat diperoleh dengan menggunakan rumus Slovin (Husein Umar, 2005), yaitu:

$$
\begin{aligned}
\mathrm{n}= & \frac{\mathrm{N}}{1+\mathrm{Ne}^{2}} \\
& =\frac{3.570 .272=99,40(100 \text { responden })}{1+3.570 .272(0,1)^{2}}
\end{aligned}
$$

Dimana:

$\mathrm{n}=$ Besar Ukuran Sampel

$\mathrm{N}=$ Jumlah Populasi

$\mathrm{e}=$ Batas Kesalahan $(10 \%)$

Jadi, jumlah sampel yang diambil dalam penelitian ini adalah 100 orang Responden.

\section{HASIL DAN PEMBAHASAN}

Proses pengujian kuisioner menunjukkan bahwa kuisioner penelitian terdiri dari 18 pertanyaan, dimana 4 pertanyaan untuk variabel X1(Ambient Condition), 5 pertanyaan untuk variabel X2 (Spatial Layout/Function), 4 pertanyaan untuk variabel X3(Sign Symbol/Artefac), serta 5 pertanyaan untuk variabel Y (Kepuasan Konsumen) memenuhi syarat validasi dan reliabilitas.

Data penelitian tersebut dianalisis menggunakan analisis regresi linier berganda yang diolah dengan software IBM SPSS Statistics 25. Adapun analisa 
tersebut bertujuan untuk mengetahui pengaruh dari servicescape yang terdiri dari Ambient Condition, Spatial Layout/Function dan Sign Symbol/Artefac terhadap kepuasan konsumen Coffee Shop di Jambi.

Hasil analisa data secara parsial setiap variabel memberikan pemahaman dan penjelasan yang berbeda. Dibawah ini penyajian hasil analisa menunjukkan bahwa:

1. Variabel Ambient Condition $\left(\mathrm{X}_{1}\right)$

Bahw terdapat pengaruh yang signifikan pada dimensi Ambient Condition terhadap kepuasan konsumen. Dari hasil pengujian diperoleh untuk variabel $\mathrm{X}_{1}$ diperoleh level signifikansi sebesar 0,010 yang bernilai lebih kecil dari nilai $\alpha=0,05$ dan berarah positif. Dari hasil tersebut dapat dinyatakan bahwa secara parsial variabel Ambient Condition berpengaruh terhadap kepuasan konsumen Coffee Shop di Kota Jambi.

2. Variabel Spatial Layout/Function $\left(\mathrm{X}_{2}\right)$

Bahwa terdapat pengaruh yang signifikan pada dimensi Spatial Layout/Function terhadap kepuasan konsumen. Dari hasil pengujian diperoleh untuk variabel $\mathrm{X}_{2}$ diperoleh level signifikansi sebesar 0,000 yang bernilai lebih kecil dari nilai $\alpha=0,05$ dan berarah negatif. Dari hasil tersebut dapat dinyatakan bahwa secara parsial variabel Spatial Layout/Function berpengaruh terhadap kepuasan konsumen Coffee Shop di Kota Jambi.

3. Variabel Sign Symbol/Artefac $\left(\mathrm{X}_{3}\right)$

Bahwa terdapat pengaruh yang signifikan pada dimensi Sign Symbol/Artefac terhadap kepuasan konsumen. Dari hasil pengujian diperoleh untuk variabel $\mathrm{X}_{3}$ diperoleh level signifikansi sebesar 0,008 yang lebih kecil dari nilai $\alpha=0,05$ dan berarah positif. Dari hasil tersebut dapat dinyatakan bahwa secara parsial variabel Sign Symbol/Artefac berpengaruh terhadap kepuasan konsumen Coffee Shop di Kota Jambi.

Untuk mengetahui tingkat kekautan peran setiap variabe dapat diketahuan bahwa dari ketiga variabel tersebut, variabel yang mendekati signifikansi 0,000 adalah variabel Spatial Layout/Function. Artinya bahwa variabel Spatial Layout/Function adalah faktor dominan dalam mempengaruhi kepuasan konsumen Coffee Shop di Kota Jambi. 
Semetara itu, hasil analisis membuktikan bahwa besarnya pengaruh Ambient Condition, Spatial Layout/Function dan Sign Symbol/Artefac secara parsial terhadap kepuasan konsumen Coffee Shop di Kota Jambi yaitu besarnya pengaruh Ambient Condition adalah $(0,257)^{2}=0,066$ atau sebesar 6,60\%, artinya Ambient Condition mempengaruhi kepuasan konsumen sebesar 6,60\%. Besar pengaruh Spatial Layout/Function adalah $(0,368)^{2}=0,1354$ atau sebesar $13,54 \%$, artinya Spatial Layout/Function mempengaruhi kepuasan konsumen sebesar 13,54\%. Kemudian besar pengaruh Sign Symbol/Artefac adalah $(0,265)^{2}=0,070$ atau sebesar 7\%, artinya Sign Symbol/Artefac mempengaruhi kepuasan konsumen sebesar $7 \%$.

\section{Pembahasan}

\section{Pengaruh Ambient Condition Terhadap Kepuasan konsumen}

Berdasarkan hasil analisa statitstik bahwa pengaruh dimensi Ambient Condition yang menjelaskan tentang pandangan konsumen mengenai karakteristik lingkungan tercermin dari emosional, persepsi atau sikap prilaku seseorang. Dalam penelitian ini ambient condition akan memiliki arti atau memberikan kepuasan yang optimal kepada konsumen apabila suasana lingkungan memiliki ciri atau karaktersitik yang berbeda dalam penyajian musik, warna, pencahayaan, aroma dan suhu udara di lingkungan Coffee Shop.

Sebagaimana hipotesis penelitian pertama yang diungkapkan sebelumnya, bahwa Ambient Condition berpengaruh signifikan terhadap kepuasan konsumen Coffee Shop di Kota Jambi. Berdasarkan hasil pengujian signifikansi parameter individual (uji statistik t) pada tabel output seperti yang penulis tampilkan pada Tabel 5.19.Dari tabel tersebut dapat dilihat bahwa nilai signifikansi t lebih besar dari $\alpha(0,05)$, sehingga dapat disimpulkan bahwa terdapat pengaruh yang signifikan antara variabel Ambient Condition terhadap kepuasan konsumen Coffee Shop di Kota Jambi.

Pada hasil bahasan empiris Firdaus Hidayat (2013) juga membuktikan bahwa terdapat pengaruh signifikan antara servicescape yang terdiri dari variabel ambient condition $\left(\mathrm{X}_{1}\right)$, spatial layout and functionality $\left(\mathrm{X}_{2}\right)$, dan sign, symbol and artifactSign Symbol/Artefac $\left(\mathrm{X}_{3}\right)$ terhadap kepuasan konsumen. 


\section{Pengaruh Spatial Layout/Function Terhadap Kepuasan konsumen}

Dimensi Spatial Layout/Function merupakan dimensi utama lain dari lingkungan layanan.Spatial Layout/Function atau tata letak spasial dan fungsionalis merupakan rancangan lantai, ukuran, dan bentuk perabotan, meja konter, mesin, serta peralatan potensial dan bagaimana semua ini disusun.

Menjawab hipotesitis kedua penelitian ini, membuktikan bahwa Spatial Layout/Function berpengaruh signifikan terhadap kepuasan konsumen Coffee Shop di Kota Jambi. Berdasarkan hasil pengujian signifikansi parameter individual (uji statistik t) pada tabel output seperti yang penulis tampilkan pada Tabel 5.19.Dari tabel tersebut dapat dilihat bahwa nilai signifikansi t lebih besar dari $\alpha(0,05)$, sehingga dapat disimpulkan bahwa terdapat pengaruh yang signifikan antara variabel Spatial Layout/Function terhadap kepuasan konsumen Coffee Shop di Kota Jambi.

Senada dengan temuan Firdaus Hidayat (2013) bahwa terdapat pengaruh yang signifikan antara servicescape yang terdiri dari variabel ambient condition $\left(\mathrm{X}_{1}\right)$, spatial layout and functionality $\left(\mathrm{X}_{2}\right)$, Symbol/Artefac $\left(\mathrm{X}_{3}\right)$ terhadap kepuasan konsumen. Begitu juga pengaruh dimensi kedua ini tidak jauh berbeda dengan temuan Meika (2014) yang menunjukkan hubungan positif antara spatial layout and functionality $\left(\mathrm{X}_{2}\right)$ terhadap kepuasan konsumen.

\section{Pengaruh Sign Symbol/Artefac Terhadap Kepuasan konsumen}

Secara umum temuan penelitian ini menunjukkan ada hubungan yang signifikan, dan tidak terkecuali dimensi artefac. Variabel ini memberikan sinyalemen berupa benda yang ditempatkan di dalam lingkungan layanan. Simbol atau artefac memiliki fungsi sebagai sinyal eksplisit atau implisit untuk mengkomunikasikan citra perusahaan, membantu pelanggan dalam menemukan apa yang mereka cari, dan menyampaikan skenario layanan. Pelanggan yang baru pertama kali datang akan langsung mencoba mengartikan makna dari lingkungan di sekitarnya untuk membantu pelanggan itu dalam melangsungkan proses jasa.

Terkait penjelasan empiris mengenai hipotesis ketiga dalam penelitian ini, bahwa Sign Symbol/Artefac berpengaruh signifikan terhadap kepuasan konsumen Coffee Shop di Kota Jambi adalah terbukti. Apabila di lihat dari hasil pengujian signifikansi parameter individual (uji statistik t) pada tabel output seperti yang 
penulis tampilkan pada Tabel 5.19.Dari tabel tersebut dapat dilihat bahwa nilai signifikansi t lebih kecil dari $\alpha(0,05)$, sehingga dapat disimpulkan bahwa terdapat pengaruh yang signifikan antara variabel Sign Symbol/Artefac terhadap kepuasan konsumen Coffee Shop di Kota Jambi.

Pengaruh variabel artefac dalam penelitian ini mendukung temuan Firdaus Hidayat (2013). Secara eksplisit menunjukkan bahwa terdapat hubungan signifikan antara servicescape yang terdiri dari variabel ambient condition $\left(\mathrm{X}_{1}\right)$, spatial layout and functionality $\left(\mathrm{X}_{2}\right)$, dan sign, symbol and artifactSign Symbol/Artefac $\left(\mathrm{X}_{3}\right)$ terhadap kepuasan konsumen.

Pengaruh simulatan antara Ambient Condition, Spatial Layout/Function dan Sign Symbol/Artefac terhadap Kepuasan konsumen

Dalam penelitian ini di hipotesis bahwa Ambient Condition, Spatial Layout/Function dan Sign Symbol/Artefac secara simultan berpengaruh signifikan terhadap terhadap kepuasan konsumen Coffee Shop di Kota Jambi. Dengan melihat hasil pengujian signifikansi parameter secara keseluruhan (uji statistik F) membuktikan bahwa signifikansi parameter lebih kecil dari nilai $\alpha(0,05)$, sehingga dapat disimpulkan terdapat pengaruh yang signifikan antara servicescape ( Ambient Condition, Spatial Layout/Function dan Sign Symbol/Artefac secara bersama-sama terhadap kepuasan konsumen Coffee Shop di Kota Jambi.

Secara empiris penelitian ini memberikan dukungan pada Firdaus Hidayat (2016) terkait bahasan mengenai pengaruh Dimensi Lingkungan Fisik (Servicescape) Terhadap Kepuasan Konsumen Kafe Sosial Place di Bandar Lampung. Dengan kata lain terdapat pengaruh yang signifikan antara servicescape terhadap kepuasan konsumen. Begitujuga bahasan Meika (2014) dan Ferninda (2013) mayoritas memberikan output nilai signifikan antara Sign Symbol/Artefac terhadap kepuasan konsumen lebih kuat dibandingkan dengan variabel Ambient Condition, Spatial Layout/Function.

\section{Kesimpulan}

Secara umum bahwa untuk bisnis Coffe Shop kepuasan konsumen dapat dijelaskan dari penilaian konsumen terkait servicescape (Ambient Condition, Spatial Layout/Function dan Sign Symbol/Artefac). Sementara itu 
untuk lebih meningkatkan pelayanan prima Coffe Shop harus lebih operasional dalam hal Spatial Layout/Function.

\section{Saran}

Berdasarkan hasil penelitian dan pembahasan diatas, ada beberapa hal yang peneliti sarankan kepada pihak yang bersangkutan yaitu sebagai berikut:

1. Coffe Shop akan memberikan kepuasan optimal apabila mampu menyajikan musik terupdate dan mengikuti trend dan suasana yang nyaman.

2. Bagi peneliti selanjutnya sebaiknya mengembangkan model penelitian dengan variabel lain seperti diversifikasi produk.

3.

\section{Daftar Pustaka}

Badan Pusat Statistik Provinsi Jambi, (2019). https://jambi.bps.go.id/download 24-1-2019.

Detik. (2019). Bisnis Coffe Shop Sangat Menguntungkan Jika Memahami Kopi Secara

Penuh. http://food.detik.com/read/2014/05/12/103620/2579841/314/bisnis-coffeshop-sangat-menguntungkan-jika-memahami-kopi-secara-penuh diakses pada tanggal 4 Februari 2019.

Ferninda, Manopo (2013). Kualitas Pelayanan dan Servicescape Pengaruhnya Terhadap Kepuasan Konsumen Pada Hotel Gran Puri Manado.

Firdaus, Hidayat (2016). Pengaruh Dimensi Lingkungan Fisik (Servicesape) Terhadap Kepuasan Konsumen (Studi pada Kafe Sosial Place di Bandara Lampung), Universitas Lampung.

Husain Umar. 2005.Manajemen Riset dan Perilaku Konsumen. PT. Gramedia Pusat: Jakarta

Lovelock, Christopher, Jochen Wirzt,Jcky Mussry (2014). Pemasaran Jasa: Manusia,Teknologi dan Strategi).Erlangga. Jakarta.

Meika, Putra Pratama, Retno Setyorini.(2014). Pengaruh Servicescape Terhadap Kepuasan Konsumen Kafe Roti Gempol dan Kopi Anjis Cabang Jalan Bengawan Bandung.

Kotler, Philip, dan Keller, Kevin Lane.(2013). Marketing Management 14th Edition Pearson Horizon Edition. England:Pearson Education.Inc 
Zeithaml, Valarie A dan Bitner, M.J. (2003). Service Marketing. Tata McGrawHill. 